\title{
Role of Push Vs Pull Factors in Employee Job Switch Decision
}

\author{
Muhammad Zohaib Sufyan \\ Azra Maqsood
}

\begin{abstract}
Man has always been the most complicated living being on this planet. It is considered next to impossible to accurately predict the behavior of human beings for any stimulus and the same stimulus generates different responses in different individuals. Considering the complicated nature of human beings, this research aims at finding out the role of different push vs. pull factors in employee job switch decision making. In this research, variables like compensation, job security, growth, promotion and development opportunity, better title/designation or compensation offered, work life balance, job employee fit etc. are taken into account to measure this role. A convenience sample of 60 respondents in a questionnaire based survey, there were 20 participants each from three companies which include Getz Pharmaceuticals, Barclays Bank PLC, Pakistan and Engro Polymer \& Chemicals Ltd. The idea was to cover three major sectors of Pakistan. Unfair Compensation took the lead in the agreement percentage in respect of factor responsible for job switch decision with $76 \%$ agreement.
\end{abstract}

Keywords: Job switch decision, employee turnover, push/pull factors in job switch, job switch factors

\section{Introduction}

Employee retention has always been one of the biggest challenges of HR practitioners and complex nature of Human Beings make it more difficult to find out what is bothering them out there. (Taylor, 2002)

Across the world, HR professionals are trying to find out common trends in the factors responsible for influencing employees to take the job switch decision. Even amid the serious economic downturn that Pakistani Economy is facing and with the worst of the unemployment rate figures, job switch decisions have also increased in numbers. Most employers blame pull factors to be responsible for their employee turnover and resist that there exist push factors within the organization which are responsible to a greater percentage for this problem. (Randle, 2007)

There are host of factors which can be held responsible for employees taking this decision harming the organization's performance. In some cases the decision also affects the employee's career itself but still they make this suicidal attempt.

Muhammad Zohaib Sufyan is working as HR Officer in Engro Polymer Chemicals Ltd., zsufyan@yahoo.com Azra Maqsood is Assistant Professor.

Journal of Independent Studies and Research - MSSE

Volume 8

Number 1

January 2010|95 


\subsection{Background}

The concept started when economist in the early days developed the theory of demand and supply and generalized it to commodity as well as the labor markets by saying that equilibrium of Demand and Supply gives the point where price and quantity is determined. In defining the job search behavior, Wildhagen (2005) takes the idea of neoclassical economics by saying "labor markets function because workers (supply side) move to locations of higher demand".

This all became a very important part of organizational behavior literature which include Luthans et al. (1995), who in his famous book on organizational behavior defines motivation to be "a process that starts with the physiological and psychological deficiency or need that activate behavior or a derive that is aimed at goal or incentive." He adds on saying that it's a relationship between needs, derives and incentives. Then a campaign of finding out the needs was started with Maslow (1954) who in his theory of hierarchy of needs pioneered in explaining the variables as to what motivates a person. Maslow's theory was generalized to all the people in the world in every situation and had certain limitations into it which made it saw great criticism; hence it was a first step of the great beginning in this field. Many of the researcher in this field refined the theory of Maslow which includes Motivation-Hygiene theory given by Herzberg (1959), ERG Theory presented by Alderfer (1969), McClelland's theory of needs (1961), Goal setting theory by Locke (1968), Victor Vroom's (1964) Expectancy Theory and the names continues.

These all were the theories complementing each other's ideas of defining the need variables that motivate people in different situations. Robins (1998) in his book on organizational behavior explained how these theories can help in motivating professionals at workplace by saying that "they have long and strong commitment to the field of their expertise. Their loyalty is more often to their profession then their employer." He adds on by saying that "money and promotion are low on their priority lists. The chief reward in their job is the work itself. Professionals also value support". Robins (1998) then gave very practical guidelines in motivating different kind of people at the workplace in the light of the theories presented by earlier OB experts.

Further research in this area has given new directions to the OB experts. Hersey et al. (1996, p.25) quotes Sigmund Freud as "one of the first to recognize, the importance of subconscious motivation. He believed that people are not always aware of everything that they want. Hence much of their behavior is affected by subconscious motives or needs. Identifying motivators and measuring their intensity in taking a job switch decision is one of the key elements of this research.

\subsection{Problem Statement}

Our main purpose of the study is to find out the role of different factors (push and pull both) responsible for job switch decision of the employees, therefore establishing "Role of Push Vs. Pull Factors in employees' job switch decision making." 
Randle (2007) and Wildhagen et al. (2005) categorize these factors into following broad categories:

- $\quad$ Push Factors (Internal to Organization)

- $\quad$ Pull Factors (External to Organization)

- Human Capital Factors

For the purpose of this study only pull and push factors will be analyzed. The decision of Employee Job Switch is making it more and more difficult for today's employers' today to retain the talent and capitalize on them for company's growth. Certain sectors of Pakistani market are being worst effected by this menace, especially Banking, Pharmaceuticals, FMCG etc are names worth mentioning. Another way we can categorize this is according to the field of specialization. In that Sales, Marketing, Production are the fields worst affected.

It is very difficult to find out exactly which factors have the highest rating as being responsible for job switch decision and then generalizing it to the employees from all sectors and field of specialization. So the factors are generalized into two aforementioned broad categories and the study will indicate which category is more responsible for employee job switch decision.

This study would be entirely from the employee's point of view.

\subsection{Variables for the study}

To the question of 'why people leave organizations?' Martin Jr. (1979), Taylor (2002) and Brown (2005) have identified following as some of the factors responsible:

- $\quad$ Push Factors

- Compensation package of current company

- Behavior of Supervisor and co-workers (peers and subordinates)

- Job-Employee Match

- Work-Life Balance

- Job Security

- $\quad$ Promotion Opportunities

- Professional Development

- Autonomy at work

- Insufficient Recognition and Appreciation

- Working Conditions 


\section{- $\quad$ Pull Factors}

- $\quad$ Compensation Package Offered

- Designation Offered

- Goodwill of the company from where offer is made

\subsection{Research Objectives}

The sole objective on which this research is focused on is:

- Which factors assume the highest responsibility for employee job switch decision?

\subsection{Research Methodology}

The research is qualitative in nature and would be based on data obtained from the primary and secondary sources. The primary source is the data collected from different corporate executives who have at least taken one job switch decision in their entire career history. Data collection tool is a survey questionnaire developed on the corelations already developed by Martin in 1979. Respondents were asked to fill out a questionnaire in the absence of researcher and without writing a name on it to ensure reliable, valid feedback.

Convenience Sampling was done and participants from three sectors including Pharmaceuticals, Banking and Chemical Processing were taken into account. An analysis of push vs. pull was carried out through a questionnaire developed according to the co-relations developed by Martin in 1979 and in consultation with the supervisor of this research (Ms. Azra Maqsood, Former Deputy Director SZABIST) Following three organizations were selected from each of the sectors identified in section 2.6 of this report

1. Barclays Bank PLC, Pakistan

2. Getz Pharma (Pvt.) Ltd.

3. Engro Polymer \& Chemicals Ltd.

20 participants on convenience were selected from these three organizations to cover three sectors including Pharmaceuticals, Banking and Chemical Processing will be taken into account for this study.

The secondary sources include journals, magazines, newspapers, and internet sites that contains matter on this subject. 


\section{Employee Turnover Intentions}

\subsection{Employee Turnover in Asia}

Following were some of the most important findings of this study by Khatri et al, (2001, p. 68-70)

- $\quad$ Age and level of education were unimportant in predicting employee turnover.

- Tenure was positively associated with turnover intention. If an individual has been in one job for a long time, he or she starts feeling a need to change his or her job perhaps because so many people are doing so.

- $\quad$ Procedural justice was found to be more important than distributive justice

- $\quad$ Satisfaction with nature of work was non-significant across all industries.

- $\quad$ Organizational commitment was found to be the most important factor influencing turnover intention.

Perceived alternative employment opportunities were a poor predictor of turnover intention at best

\subsection{Employee development and Intentions of Turnover}

The idea Benson (2006) gives in the study is that personal and professional development is a way for any employee for a career progress and if company does not arrange for such kind of employee development programs then employees will do it themselves and after completion of this development, want to switch to a higher position. If this position is not given in the same company, employees will decide to move to another firm where this goal can be fulfilled. He further adds that the higher wages associated with higher position is the key factor working behind this phenomenon.

\subsection{Model of Voluntary Employee Turnover based on Image Theory}

This research was very significant in a way that it unfolded the new dimensions of employee turnover and termed it as a "complex process". The findings of this model can be summarized into following 7 points. (Lee et. al, 1994 p. 86)

1. The existing models of employee turnover are too simple; leaving an organization can take place in many different ways.

2. One of the major precipitating events for employee turnover is the shock to the system-an event that prompts an individual to evaluate his or her current and perhaps other jobs.

3. Shocks are not just negative job-related factors; positive and neutral events that are both job and non-job related can prompt mental deliberations about leaving.

4. In some cases, employees simply leave because the shock results in scripted behavior, where no extensive cognitive deliberations that evaluate the current 
or alternative jobs take place.

5. Some employees leave organizations without considering alternatives; their central choice is to stay or leave their present company-not to quit for another organization.

6. In most cases, employees make decisions about staying with or leaving an organization based on a fit or compatibility criterion, rather than on maximizing their subjective expected utilities.

7. Employee turnover occurs over time; only by developing methods that assess how the process evolves will researchers and managers understand why individuals chose to leave.

\section{Analysis of Pull vs Push Factors}

\subsection{Push Factors}

\section{Compensation package of the current company}

a. $\quad 75 \%$ participants agree about importance of this factor as responsible to make employees take job switch decision.

b. Females are more concerned about fair compensation than men

c. People with larger dependency burden are the one who think that their compensation level is not according to what they deserve

d. Mid career people or senior level employees are more concerned about their compensation than their juniors (starters) counterparts

\section{Behavior of Supervisor}

a. $\quad 31 \%$ participants agree about the importance of this factor as responsible to make employees take job switch decision.

b. people with higher level of experience are more interested in supervisors' recognizing their opinion and contribution in comparison to people with lower level of experience

3. Behavior of Co-Worker (Peer and Sub-ordinate)

a. People with higher level of experience are more interested in supervisors' recognizing their opinion contribution in comparison to people with lower level of experience

4. Job employee match

a. A higher level of disagreement and neutral replies shows almost no relationship between the two factors

\section{Work-Life Balance}

a. Mostly people remain neutral about this statement because in this time of intense competition, every job has high demands which mean working for 
long hours.

b. People with the higher level of experience are interested in having a job which provides them with work-life balance than people with lower experience level.

c. A consistent $30+\%$ people agreed to switch a job if they are offered a job with the better work-life balance. This shows some amount of relation between the two factors

6. Job Security

a. $45 \%$ of participants do agree with it, however, $24 \%$ were neutral

b. Females, People with high level of dependency burden and the mid career people have shown their strong agreement to this statement because a job loss to them would mean a lot than people in any other category. They think that its better to quickly start a job search when they feel that their present job is not secure

c. Males, single and people with lower dependency burden will always think to continue with the same job because a job loss to them is not as devastating as in other categories.

7. Promotion Opportunities

a. $60 \%$ of respondents agree to this statement and hence can be said to have strong relationship with job switch decisions

b. People with the higher level of experience and also those holding Bachelors Degree are a lot more concerned about promotion opportunities and higher percentage of them decides to quit if they feel their growth is stagnant in the current company/job.

c. Most of the singles and people with less than 3 years of experience feel that growth opportunity is not a reason which can be used to quit the job.

8. Professional Development

a. No significant relationship between lack of professional development opportunities.

9. Autonomy at Work

a. A greater percentage of people disagree with the idea that lack of autonomy of work can be so intense for them that they take the job switch decision.

10. Recognition and Appreciation

a. Somewhat a good relationship of this factor with only $19 \%$ people disagreeing with the idea and the rest either agree to it or remain neutral with it.

11. Working Conditions

a. Only $18 \%$ disagreed with the idea make it a fairly important factor to 
generate job switch feelings in the employees

\subsection{Pull Factors}

1. Compensation package offered by other companies

a. With $38 \%$ agreement and $42 \%$ neutral responses make it another fairly important factor responsible for employee job switch decision.

2. Designation offered by the other companies

a. $\quad 67 \%$ per cent agreement and $20 \%$ neutral responses make this factor a very important one for employees to consider when taking a job switch decision

b. Males are more responsive to designation/title than females

c. Married and people with higher dependency burden are also looking designation as very important

d. People with the higher experience level are extremely responsive to designation than people with lower experience level.

3. Goodwill of the company from where offer is made

a. With $38 \%$ agreement and $42 \%$ neutral responses make it another fairly important factor responsible for employee job switch decision.

b. Again a $58 \%$ agreement and $27 \%$ of neutral responses make it a very important pull factor that employee's consider while thinking of job switch.

c. People with higher dependency burden and higher level of experience think that goodwill of the company is an important factor than any other category

\section{Conclusion}

According to agreements received in this research, following are the rankings of factors responsible for job switch decision making

1. Unfair compensation compare to what is deserved (Push) $\mathbf{7 6} \%$

2. Designation / Title offered by another company (Pull) $67 \%$

3. Unfair compensation given as compare to others with similar profile in the company (Push) 65\%

4. Reputation of the Company making the offer (Pull) $\mathbf{5 8 \%}$

5. Promotion Opportunities (Push) $55 \%$

6. Job Security (Push) $\mathbf{4 5 \%}$

7. Recognition / Appreciation from the company (Push) $\mathbf{4 2} \%$

8. Compensation Offered by another company (Pull) $\mathbf{3 8 \%}$

9. Working Conditions (Push) $\mathbf{3 6 \%}$

Journal of Independent Studies and Research - MSSE

Volume $8 \quad$ Number 1

January 2010 102 
10. Employee Supervisor Relationship (Push) $\mathbf{3 3 \%}$

11. Work Life balance (Push) $33 \%$

12. Professional Development Opportunities (Push) 29\%

13. Autonomy at work (Push) $\mathbf{2 2} \%$

14. Co-worker relationship (Push) $\mathbf{2 0 \%}$

15. Job Employee Match (Push) $13 \%$

The rankings given above are very much self explanatory and suggest that push and pull factors both are very important with compensation package of the current company being declared to be the most important one. Another important set of conclusions that can be drawn out of cross analysis done in each of the variable study in section 4.2 and 4.3 of this report, that there exist differences in the importance for each puch and pull factor according to gender, marital status, education level, dependency burden and experience level. 


\section{References}

Alderfer, C. P. (1969) An Empirical Test of New Theory of Human Needs, Organization Behaviour and Human Performance, May 1969, pp. 142.

Beale, Andrew V., et al. (2002) Achieving Congruence between Employee Interests and County Jobs: a win-win proposition, Journal of Employment Counseling, March 2002, Volume 39, No. 1, pp. 22-30..

Benson, George S. (2006), Employee development, commitment and intention to turnover: a test of 'employability' policies in action, Human Resource Management Journal, Volume 16, Issue 2, Page 173-192, Apr 2006

Brown, Collin. (2005) 10 Reasons Employees Leave, Employee Retention Guide, UK retrieved Jan. 24, 2009 from http://www.employee-retention-guide.com/10-reasons.pdf

Dalton, Dan R. et. al (1982) Turnover: A Lucrative Hard Dollar Phenomenon, The Academy of Management Review, Vol. 7, No. 2, Apr., 1982, pp. 212-218.

Hersey, Paul et al. (1996) Management of Organizational Behavior, 7th Ed., PrenticeHall of India Pvt. Ltd.

Herzberg, Fredrick et al. (1959) The Motivation to Work, New York, John Wiley Khatri Naresh, et al. (2001), Explaining employee turnover in an Asian context, Human Resource Management Journal, Volume 11, Issue 1, Jan 2001, Page 54-74.

Lee, Thomas W. et al. (1994), An Alternative Approach: The Unfolding Model of Voluntary Employee Turnover, The Academy of Management Review, Vol. 19, No. 1, Jan., 1994, pp. 51-89.

Locke, E.A. (1968) Towards the Theory of Task Motivation and Incentives, Organizational Behaviour and Human Performance, May 1968, pp. 157.

Luthans, Fred et al. (1995) Organizational Behavior, United States, McGraw-Hill Publications.

Martin, Jr., Thomas N. (1979) A Contextual Model of Employee Turnover Intentions, Academy of Management Journal, Vol. 22, No. 2, Jun., 1979, pp. 313-324.

Maslow, Abraham (1954) Motivation and Personality, New York, Harper Row McClelland, D.C. (1961) The Achieving Society, New York, Van Nostrand Reinhold. Randle, Francesca (2007), How do I ensure successful retention strategy? www.callcentrehelper.com/how-do-i-ensure-a-successful-retention-strategy-183.htm 
Robbins, Stephen P. (1998) Organizational Behavior, New York, Prentice-Hall, Inc.

Taylor, Stephen (2002), Employee Retention Handbook, United Kingdom, CIPD Publishing Vroom, Victor (1964) Work and Motivation, New York, John Wiley

Wildhagen, Tina et al. (2005), Factors Leading to Clergy Job Search in Two Protestant Denominations, Review of Religious Research, Vol. 46, No. 4, pp. 380-402.

Wilkes, Angeline (2006), The disconnect between Management Perception and Reality, www.workforceretention.com.au/research_papers.php?article $=6$ 